DOI: 10.17951/lrp.2019.38.3.271-283

\author{
Marzena Kowaluk-Romanek \\ Uniwersytet Marii Curie- Skłodowskiej \\ Wydział Pedagogiki i Psychologii. Instytut Pedagogiki \\ ORCID - 0000-0002-5579-6240
}

\title{
RYZYKO DYSLEKSJI A STRATEGIE RADZENIE SOBIE W SYTUACJACH TRUDNYCH SPOŁECZNIE PRZEZ DZIECI W MŁODSZYM WIEKU SZKOLNYM
}

\begin{abstract}
Streszczenie: Przeprowadzone badania własne wpisują się w nurt doniesień empirycznych dotyczących radzenia sobie w sytuacjach trudnych przez dzieci. Ich celem była próba odpowiedzi na pytanie, czy i w jaki sposób ryzyko dysleksji wpływa na radzenie sobie w sytuacjach trudnych społecznie przez dzieci w młodszym wieku szkolnym. Badaniami objęto 64 uczniów klas II i III szkół podstawowych województwa lubelskiego. Grupę podstawową stanowili uczniowie ze zdiagnozowanym ryzykiem dysleksji, porównawczą zaś - ich rówieśnicy niemający specyficznych trudności w uczeniu się. Badania wykazały, że między grupami zachodzą różnice istotne statystycznie w obrębie dwóch skal: współpraca i unikanie. Dzieci ryzyka dysleksji w sytuacjach trudnych społecznie zdecydowanie rzadziej niż ich rówieśnicy stosują strategię współpracy. Zamiast efektywnej strategii radzenia sobie w sytuacjach stresowych pojawiają się u nich różnorodne - nieukierunkowane na rozwiązanie i przezwyciężenie problemu - sposoby obrony. Dominuje u nich strategia unikania. W porównaniu z rówieśnikami zdecydowanie częściej nie podejmują działań zmierzających do rozwiązania sytuacji trudnej. Dzieci ryzyka dysleksji oraz dzieci bez trudności w uczeniu się z podobną częstotliwością stosują nieefektywne strategie radzenia sobie w sytuacjach trudnych, takie jak: agresja i uleganie.
\end{abstract}

Słowa kluczowe: dzieci w młodszym wieku szkolnym, ryzyko dysleksji, radzenie sobie w sytuacjach trudnych społecznie

\section{WPROWADZENIE}

Sytuacje trudne są nieodłączną częścią życia człowieka, towarzyszą mu od wczesnego dzieciństwa. Już od narodzin każdy z nas musi nauczyć się radzić sobie z trudnościami i wyzwaniami. Dzieciństwo powinno kojarzyć się z miłością 
i troską najbliższych, z poczuciem spokoju i bezpieczeństwa, jednak wiele danych wskazuje, że coraz młodsze dzieci przeżywają okoliczności przerastające ich możliwości adaptacyjne, doświadczają sytuacji trudnych często odbijających się negatywnie na ich rozwoju, edukacji oraz funkcjonowaniu w rodzinie, szkole, grupie rówieśniczej.

Problematyką sytuacji trudnych zajmowało się wielu badaczy. Na gruncie psychologii twórcą teorii sytuacji i sytuacji trudnych jest Tadeusz Tomaszewski, który twierdzi, że z sytuacją trudną mamy do czynienia, wówczas gdy „wewnętrzna równowaga sytuacji normalnej zostanie zachwiana tak, że normalny przebieg aktywności podstawowej zostanie zakłócony i prawdopodobieństwo realizacji zadania na poziomie normalnym stanie się mniejsze" (1982, s. 32). Przez sytuacje trudne - zdaniem autora - należy rozumieć „takie sytuacje, w których zachodzi rozbieżność między potrzebami lub zadaniami człowieka a możliwościami zaspokojenia tych potrzeb lub wykonania zadań" (Tomaszewski 1984, s. 134). Autor wyodrębnia kilka typów trudności, którym przypisuje znaczenie stresowe, są nimi: sytuacja deprywacji (niezaspokojenia ważnych dla podmiotu potrzeb), sytuacja przeciążenia (trudność zadania jest na granicy możliwości podmiotu), sytuacja utrudnienia (zmniejszona możliwość wykonania zadania), sytuacja zagrożenia (zwiększone prawdopodobieństwo naruszenia cenionej wartości) i sytuacje konfliktowe (występowanie przeciwstawnych sił fizycznych lub sprzecznych nacisków moralnych, społecznych czy światopoglądowych). Wymienione sytuacje trudne wzajemnie się warunkują - w określonej sytuacji możemy spotkać się z różnego rodzaju trudnościami, na przykład sytuacja zagrożenia może łączyć się zarówno z deprywacją, jak i utrudnieniem czy przeciążeniem (Tomaszewski 1984).

Maria Tyszkowa - nawiązując do teorii sytuacji trudnej Tadeusza Tomaszewskiego i regulacyjnej teorii stresu Janusza Reykowskiego - uważa, że sytuacja trudna to „taki układ zadań (celów), warunków działania i możliwości działającego podmiotu, w jakim naruszona została równowaga między tymi elementami w stopniu wymagającym nowej koordynacji stosunków podmiotu z otoczeniem, co powoduje przeciążenie systemu psychicznej regulacji i emocje ujemne. W konsekwencji trwania tego stanu pojawiają się zmiany w zachowaniu jednostki, a między innymi reorganizacja lub dezorganizacja ukierunkowanej na cel czynności” (Tyszkowa 1997, s. 475). W przytoczonych definicjach sytuacji trudnej rozpatrywanej w kategoriach relacji między człowiekiem a otoczeniem przypisuje się status terminu „stres psychologiczny” (por. Terelak 1995). Tak rozumianą sytuację trudną określa się często mianem sytuacji stresowej.

Każdy z nas jest narażony na stres, nie da się go uniknąć, można jednak spróbować mieć nad nim kontrolę. Człowiek w sytuacji stresowej nie pozosta- 
je bierny, podejmuje działania zmierzające do pokonania zagrożenia lub jego zminimalizowania. Sposobów radzenia sobie jest wiele - celem jednych jest zwalczenie czynników stresujących, jeszcze inne polegają na poprawieniu samopoczucia bez likwidowania przyczyn stresu, pozostałe wiążą się z unikaniem sytuacji trudnych, ograniczeniem okoliczności wywołujących stres (zob. Łosiak 2008, 2009).

We współczesnej zagranicznej psychologii najczęściej przytaczana jest transakcyjna teoria stresu Lazarusa i Folkman, którzy definiują go jako określoną relację „między osobą a otoczeniem, która oceniana jest przez osobę jako obciążająca lub przekraczająca jej zasoby i zagrażająca jej dobrostanowi” (1984, s. 19). Główny nacisk w tej definicji położony jest na: relację między jednostką a otoczeniem, subiektywną ocenę znaczenia tej relacji dokonywanej przez podmiot, osobiste zasoby jednostki, które zostały obciążone, w wyniku czego następuje zakłócenie równowagi między możliwościami jednostki a wymaganiami otoczenia oraz zagrożenie dobrostanu podmiotu. Podstawowe pojęcie „transakcja” łączone jest przez autorów tej teorii z kontekstem sytuacyjnym, sugeruje połączenie osoby i otoczenia w pewną jedność czy też system. Możemy wyróżnić trzy składowe zjawiska transakcji stresowej, między którymi zachodzą określone zależności: proces oceny poznawczej (ocena pierwotna, decydująca o uznaniu danej sytuacji za stresową, oraz ocena wtórna, związana z radzeniem sobie $\mathrm{z}$ tą sytuacją), proces emocjonalny (emocje stanowią składową sytuacji stresowej - są wtórne do oceny poznawczej) a także proces radzenia sobie (Lazarus, Folkman 1984).

Władysław Łosiak $(1994,2008)$ twierdzi, że radzenie sobie ze stresem w ujęciu Lazarusa i Folkman traktowane jest jako proces o określonym przebiegu. Działania podejmowane przez jednostkę są analizowane zawsze w określonej w sytuacji trudnej, bowiem w dużym stopniu od niej zależą. Formy radzenia sobie ze stresem zmieniają się w zależności od relacji jednostka - otoczenie. Można tutaj mówić o określonych strategiach radzenia sobie ze stresem.

W definicji radzenia sobie zwraca się uwagę na konieczność uwzględnienia perspektywy rozwojowej oraz odróżnienia jej specyfiki od innych reakcji indywidualnych na stres. Transakcyjne ujęcie stresu Lazarusa i Folkman (1984) zakłada, że wysiłki podejmowane w procesie radzenia sobie są ukierunkowane na utrzymanie, powiększanie czy zmienianie kontroli nad środowiskiem i samym sobą. Procesy kontroli pierwotnej koncentrują się na próbach zmiany obiektywnego zdarzenia, jego uwarunkowań i dostosowania ich do swoich potrzeb. Z kolei procesy kontroli wtórnej mają na celu zmianę samej jednostki, czyli jej dopasowania do sytuacji. Wraz z wiekiem zmniejsza się udział sposobów radzenia sobie opartych na kontroli pierwotnej, a wzrasta radzenie sobie oparte na kontroli wtórnej. Jennifer Connor- 
-Smith i jej współpracownicy (2000) wyróżniają dwa sposoby radzenia sobie ze stresem - intencjonalne, zależne od woli, oraz automatyczne (reaktywne). Jedne i drugie, ze względu na cel zachowania, mogą wiązać się z kontrolą pierwotną i wtórną. Świadome i intencjonalne strategie radzenia sobie rozwijają się później niż automatyczne reakcje na stres, gdyż wiążą się ze wzrostem różnych kompetencji nabywanych stopniowo w trakcie rozwoju jednostki. Marlene Caplan, Loisa Bennetto i Roger Weissberg (1991) dostarczyli danych wskazujących, że stosowanie wielu różnych strategii w sytuacjach trudnych, a więc pewna elastyczność w radzeniu sobie, wiąże się pozytywnie z kompetencjami społecznymi dzieci. Im starsze dziecko, tym większa skłonność do wybierania różnorodnych strategii w sytuacji doświadczanego stresu.

Definicje dysleksji koncentrują się głównie na poznawczych aspektach tego zjawiska: osiągnięciach szkolnych uczniów oraz sprawnościach powiązanych z tymi osiągnięciami. Trzeba jednak zdać sobie sprawę, że dysleksja może prowadzić zarówno do niepowodzeń szkolnych, jak i życiowych. Już uczeń ryzyka dysleksji często doświadcza porażek edukacyjnych, sporadycznie odnosi sukcesy, doświadcza bycia „innym” niż rówieśnicy, narażony jest na presję ze strony rodziców i nauczycieli. Taka sytuacja nie pozostaje bez wpływu na jego funkcjonowanie.

\section{BADANIA WŁASNE}

Na podstawie dostępnych doniesień empirycznych zasadne jest przyjęcie założenia, że dysleksja jest czynnikiem stresogennym, narażającym ucznia na przeżywanie wielu sytuacji trudnych (por. Fawcett 1995; Morgan i Klein 2000; Alexander-Passe 2006, Krasowicz-Kupis 2008). Wątpliwości, jakie się pojawiają, dotyczą relacji między dysleksją a sposobami radzenia sobie w sytuacjach trudnych społecznie przez dzieci w młodszym wieku szkolnym, których osobowość nie jest jeszcze w pełni ukształtowana, i które w znacznie mniejszym niż dorośli stopniu panują nad swoimi reakcjami emocjonalnymi.

W badaniach postawiono następujące pytanie szczegółowe: czy i w jaki sposób dzieci ryzyka dysleksji różnią się pod względem sposobów radzenia sobie ze stresem od swoich rówieśników niemających specyficznych trudności w uczeniu się?

Badania przeprowadzono za pomocą metody sondażu diagnostycznego. Wykorzystano w nich kwestionariusz Mały Kosmita autorstwa Iwony Cicheckiej-Jusińskiej i Krystyny Pławskiej (2011). Narzędzie umożliwia ustalenie sposobów radzenia sobie w sytuacjach trudnych społecznie przez dzieci w młodszym wieku szkolnym. Autorki zredagowały dwadzieścia cztery krótkie opowiada- 
nia, w których bohater - Mały Kosmita, przypadkiem mieszkający na naszej planecie - przeżywa sytuacje trudne społecznie zbliżone do zdarzeń, w jakich uczestniczą dzieci w szkole, znanych im z własnego doświadczenia. Opisywane sytuacje trudne mieszczą się w dwóch obszarach - obszar konfliktów dziecko dorosły (nauczyciel) oraz obszar konfliktów międzyrówieśniczych. Do każdego opowiadania dołączono w przypadkowej kolejności cztery wersje odpowiedzi sugerujących, jak mógłby zachować się bohater opowiadania w danej sytuacji. Zadaniem badanego, po wysłuchaniu opowiadania, jest dokonanie wyboru jednej odpowiedzi. Integralną część kwestionariusza jest klucz przypisujący wyniki do skali agresji, uległości, unikania i współpracy. Zadaniem badającego jest odczytanie wyników zgodnie z kluczem i ustalenie, jaka strategia przeważa u danego dziecka.

Rzetelność narzędzia autorki sprawdziły za pomocą zgodności wewnętrznej podkategorii alfa Cronbacha oraz metody połówkowej Spearmana-Browna. Uzyskane współczynniki zgodności wewnętrznej okazały się zadawalające.

Badaniami własnymi objęto 64 uczniów klas II i III szkół podstawowych województwa lubelskiego. Badane grupy były równoliczne. Grupę podstawową stanowili uczniowie ze zdiagnozowanym ryzykiem dysleksji, porównawczą zaś ich rówieśnicy niemający specyficznych trudności w uczeniu się. Zadbano o to, by grupy były równoważne pod względem płci, wieku i czynników socjalno-bytowych składających się na obraz środowiska rodzinnego respondentów.

\section{WYNIKI BADAŃ}

Badania przeprowadzone za pomocą kwestionariusza Mały Kosmita wykazały, że między badanymi grupami zachodzą różnice istotne statystycznie w obrębie dwóch skal: współpraca i unikanie. Dzieci ryzyka dysleksji w sytuacjach trudnych społecznie zdecydowanie rzadziej niż ich rówieśnicy stosują strategię współpracy $(t=-2,87 ; p=0,005)$ (zob. tab. 1). Różnica między grupami w zakresie danej zmiennej okazała się wysoce istotna statystycznie. Zamiast efektywnej strategii radzenia sobie w sytuacjach trudnych społecznie u dzieci ryzyka dysleksji pojawiają różnorodne - nieukierunkowane na rozwiązanie i przezwyciężenie problemu - sposoby obrony. Strategie destruktywne, nastawione na obniżenie napięcia emocjonalnego, nie rozwiązują szeroko pojętych zadań, stawianych przez otoczenie, co w dłuższej perspektywie czasowej może wywołać poczucie niezadowolenia i frustrację, a nawet prowadzić do utraty poczucia sprawstwa i kontroli, osłabiającego twórczą aktywność ucznia i jego poczucie własnej wartości (por. Borecka-Biernat 2006). 
Tabela 1. Radzenie sobie w sytuacjach trudnych społecznie

\begin{tabular}{|l|c|c|c|c|c|c|c|c|}
\hline \multirow{2}{*}{ Skala } & \multicolumn{3}{|c|}{ Grupa podstawowa } & \multicolumn{3}{c|}{ Grupa porównawcza } & \multirow{2}{*}{$\begin{array}{c}\text { Test } \\
\text { t-Studenta }\end{array}$} & $\begin{array}{c}\text { Poziom } \\
\text { istotności }\end{array}$ \\
\cline { 2 - 8 } & $\boldsymbol{N}$ & $\boldsymbol{X}$ & $\boldsymbol{S}$ & $\boldsymbol{N}$ & $\boldsymbol{X}$ & $\boldsymbol{S}$ & 2,01 & 0,04 \\
\hline Unikanie & 32 & 7,37 & 3,11 & 32 & 5,81 & 3,09 & 0,50 & n.i. \\
\hline Agresja & 32 & 4,41 & 2,43 & 32 & 4,09 & 2,57 & 0,50 & n.i. \\
\hline Uleganie & 32 & 4,44 & 2,34 & 32 & 4,06 & 2,62 & 0,60 & 0,005 \\
\hline Współpraca & 32 & 7,25 & 3,44 & 32 & 9,81 & 3,69 & $-2,87$ & \\
\hline
\end{tabular}

Dzieci ryzyka dysleksji różnią się istotnie statystycznie od swoich rówieśników pod względem stosowania w sytuacjach trudnych społecznie strategii unikania $(t=$ $2,01 ; p=0,04)$ (zob. tab. 1). W porównaniu z rówieśnikami zdecydowanie częściej nie podejmują działań zmierzających do rozwiązania sytuacji trudnej, dominuje u nich przekonane, że wszelkie próby rozwiązania problemu będą nieskuteczne. Strategia unikania jest skoncentrowana na własnym stanie emocjonalnym, napięcie emocjonalne towarzyszące uczestniczeniu w sytuacji trudnej jest na tyle silne, że dzieci wycofują się z niej najczęściej poprzez: odkładanie rozwiązania problemu na później, przekonywanie siebie i innych, że nic istotnego się nie wydarzyło czy też angażowanie się w czynności zastępcze. Posługiwanie się strategią unikową sugeruje u badanych bezsilność, brak motywacji do podejmowania działań czy nasilone odczuwanie lęku (por. Borecka-Biernat 2006).

Nie stwierdzono różnic istotnych statystycznie między badanymi grupami w skalach: agresja i uleganie. Oznacza to, że zarówno dzieci ryzyka dysleksji, jak i dzieci bez trudności w uczeniu się z podobną częstotliwością stosują wyżej wymienione strategie.

Analiza jakościowa radzenia sobie w sytuacjach trudnych społecznie wykazała, że największą różnicę między badanymi możemy zaobserwować w zakresie stosowania strategii współpracy. Wyniki niskie odnotowano aż u 62,5\% dzieci ryzyka dysleksji i tylko u $28,1 \%$ dzieci niemających trudności w uczeniu się. Taki rezultat sugeruje poważne problemy w satysfakcjonującym dla dziecka rozwiązaniu sytuacji trudnej i wiąże się z niezaspokojeniem znacznej części jego potrzeb. U żadnego z badanych z grupy podstawowej nie stwierdzono wyników wysokich świadczących o poczuciu własnej wartości, szacunku dla innych, niskim poziomie lęku oraz wysokich umiejętnościach interpersonalnych. W grupie porównawczej stanowiły one $25 \%$. Różnice między grupami dotyczyły również wyników przeciętnych. Wyniki te uzyskało 37,5\% dzieci ryzyka dysleksji oraz $46,9 \%$ dzieci bez trudności w uczeniu się.

Nieco mniejszą, ale wciąż znaczną różnicę między grupami, stwierdzono w skali unikania. Strategia ta polega na unikaniu sytuacji, w których ujawniają 
się słabości dziecka, lub odwracaniu uwagi otoczenia od tej sfery jego działania. Wysokie wyniki w tym zakresie uzyskała ponad połowa dzieci ryzyka dysleksji $(59,4 \%)$ oraz $34,4 \%$ ich rówieśników. Przeciętne wyniki odnotowano u 25\% badanych z grupy podstawowej oraz $37,5 \%$ z grupy porównawczej. Średni wynik świadczy o umiejętności dobierania strategii do problemu. Unikanie jest sensowną strategią $\mathrm{w}$ takich sytuacjach, kiedy przedmiot konfliktu jest czymś nieistotnym i kiedy jest mała szansa na jego rozwiązanie. Autorki narzędzia sugerują, że dzieci otrzymujące wyniki przeciętne, w zależności od sytuacji, potrafią posłużyć się również innymi strategiami (Cichecka-Jusińska, Pławska 2011). Różnice między badanymi dziećmi dotyczą również wyników niskich danej skali. Uzyskało je tylko $15,6 \%$ dzieci ryzyka dysleksji i $28,1 \%$ dzieci niemających trudności w uczeniu się. Wynik niski wskazuje na stosowanie strategii unikowej w nielicznych sytuacjach, Wiąże się z niskim poziomem lęku, bronieniem własnych poglądów oraz dbaniem o zaspokajanie swoich potrzeb.

Analiza jakościowa wyników pokazuje pewne różnice między badanymi w dwóch pozostałych skalach kwestionariusza - uleganiu i agresji. Wybierając większość zachowań prezentowanych w skali ulegania, dziecko rezygnuje z realizacji swoich celów, tym samym jest bardziej narażone na manipulację i skłonne do zachowań ryzykownych za cenę akceptacji i bycia lubianym. Strategia ta daje poczucie bezpieczeństwa dzieciom niepewnym siebie, które zazwyczaj uzyskują opinię sympatycznych i bezkonfliktowych (Cichecka-Jusińska, Pławska 2011). Wyniki wysokie w tej skali odnotowano u 12,5\% dzieci ryzyka dysleksji oraz 6,2\% ich rówieśników. Uleganie w stopniu średnim zaobserwowano u 46,9\% badanych z grupy podstawowej oraz $40,6 \%$ z grupy porównawczej. Wynik przeciętny w tej skali nie stanowi większego problemu, najczęściej otrzymują go dzieci, które chętnie przestrzegają norm i zasad oraz są z natury zdyscyplinowane. Wyniki niskie dotyczą 40,6\% dzieci ryzyka dysleksji oraz 53,2\% ich rówieśników.

Nieco inaczej rozkładają się wyniki uzyskane przez badanych w skali agresji. Agresywna strategia radzenia sobie w sytuacjach trudnych określa zachowania, które wyrażają negatywne emocje wobec innych poprzez obraźliwe wypowiedzi, złośliwe wyśmiewanie się, używanie siły fizycznej, niszczenie przedmiotów. Działając w ten sposób, dziecko nie rozwiązuje problemu, lecz wyładowuje swoją złość i wrogość w wyniku przeżywanej frustracji i w ten sposób uwalnia się od przykrego napięcia emocjonalnego. W tej skali badane dzieci uzyskały najwięcej wyników przeciętnych - 40,6\% respondentów z grupy podstawowej i 43,8\% z grupy porównawczej. Na drugiej pozycji uplasowały się wyniki niskie - otrzymało je $34,4 \%$ dzieci z obu grup. U najmniejszej liczby badanych odnotowano wyniki wysokie - $25 \%$ dzieci ryzyka dysleksji oraz $21,8 \%$ dzieci niemających trudności w uczeniu się. 


\section{DYSKUSJA I PODSUMOWANIE. WSKAZÓWKI DLA PRAKTYKI PEDAGOGICZNEJ}

Problematyka stresu u dzieci jeszcze do niedawna była dość rzadko przedmiotem badań. Nie stworzono dotąd teorii wyjaśniającej procesy radzenia sobie ze stresem, jakie zachodzą u dzieci, chociaż zarówno charakter sytuacji trudnych, jak i specyfika radzenia sobie różnią je od dorosłych. Konceptualizacja radzenia sobie w sytuacjach trudnych najczęściej nawiązywała do modeli dotyczących ludzi dorosłych i w niedostatecznym stopniu brała pod uwagę - istotny dla wcześniejszych okresów życia - komponent rozwoju. Od ostatniej dekady ubiegłego stulecia możemy zaobserwować wyraźny wzrost zainteresowania radzeniem sobie w sytuacjach trudnych przez dzieci. Coraz bardziej oczywiste staje się przekonanie, że strategie radzenia sobie ze stresem reprezentują ważny aspekt procesów samoregulacji emocji, poznania i zachowania. Stres psychospołeczny zaczyna być traktowany jako istotny czynnik ryzyka rozwoju psychopatologii w dzieciństwie i adolescencji. Z kolei sposoby radzenia sobie w sytuacjach trudnych stają się wyznacznikami obecnego i przyszłego przystosowania się (Compas i in. 2001; Skinder 1995).

W literaturze przedmiotu zwraca się uwagę na pewną specyficzność sytuacji będących źródłem stresu u dzieci i młodzieży. Donna Pinkus i Alice Friedman (2004) podają, że odczuwany stres najczęściej dotyczy czterech kategorii problemów: związanych z przedszkolem i szkołą, związanych z rodzicami, relacji z kolegami i koleżankami oraz pierwszych sympatii. Dla dzieci młodszych przyczynami stresu są głównie problemy przedszkolne i szkolne, konflikty z rodzeństwem, rodzicami i przyjaciółmi. Chłopcy częściej doświadczają stresu w wyniku problemów szkolnych, dla dziewczynek źródłem stresu są głównie relacje interpersonalne.

Sytuacja dzieci w zmaganiu się ze stresem jest znacznie trudniejsza niż dorosłych, dlatego że mają one zdecydowanie mniejszą kontrolę nad okolicznościami powodującymi negatywne emocje, a w związku z tym mniejsze możliwości wywierania na nie wpływu. Ich szanse poznawczej oceny sytuacji i jej logicznego wyjaśnienia są inne niż u osób dorosłych. Zachowanie dzieci w sytuacjach trudnych podlega zmianom rozwojowym. Dzieci starsze są bardziej wrażliwe niż młodsze na sytuacje zagrożenia społecznego. Wraz z wiekiem zwiększa się kontrola emocjonalna oraz zdolność do przezwyciężania trudności, zmienia się również typ reagowania na sytuację trudną. U dzieci młodszych dominują tzw. reakcje ekstrapunitywne, przejawiające się przypisywaniem winy za powstałą sytuację przedmiotom zewnętrznym i innym osobom, natomiast u dzieci starszych tzw. intrapunitywne, odzwierciedlające zwiększone poczucie winy, wzrost samokrytycyzmu. Ma też miejsce wzrost reakcji instrumentalnych prowadzących do rozwiązania zadania i następuje zwiększona skuteczność działania (Tyszkowa 1986). 
Zaprezentowane w niniejszym artykule badania własne dowodzą, że między dziećmi ryzyka dysleksji a ich rówieśnikami niemającymi specyficznych trudności w uczeniu się zachodzą różnice istotne statystycznie w obrębie dwóch, spośród czterech, strategii radzenia sobie w sytuacjach trudnych: strategii współpracy i unikania. Dzieci ryzyka dysleksji w sytuacjach trudnych społecznie zdecydowanie rzadziej niż ich rówieśnicy stosują strategię współpracy. Zamiast efektywnej strategii radzenia sobie w sytuacjach stresowych pojawiają się u nich różnorodne nieukierunkowane na rozwiązanie i przezwyciężenie problemu - sposoby obrony. Dotyczy to zarówno konfliktów dziecko - dorosły (nauczyciel), jak i konfliktów międzyrówieśniczych. Dzieci ryzyka dysleksji przede wszystkim radzą sobie w sytuacjach trudnych społecznie, stosując strategię unikania. W porównaniu z rówieśnikami zdecydowanie częściej nie podejmują działań zmierzających do rozwiązania sytuacji trudnej. Dzieci z obu badanych grup z podobną częstotliwością stosują nieefektywne strategie radzenia sobie w sytuacjach trudnych, takie jak agresja i uleganie.

Dla dzieci ryzyka dysleksji, ze względu na poznawcze aspekty tego zaburzenia, istotnym źródłem stresu jest szkoła. Uczeń doświadcza wczesnych niepowodzeń, sporadycznie odnosi sukcesy. Niskie osiągnięcia szkolne wpływają na relacje z rówieśnikami, dziecko zaczyna doświadczać negatywnej oceny kolegów i marginalizacji. Pojawia się długotrwały stres, związany z lękiem przed klasówkami i odpytywaniem, reakcjami nauczycieli, rówieśników i rodziców. Ciągłe napięcie, znaczny wysiłek włożony w naukę z pewnością skutkuje zmęczeniem i wyczerpaniem. Taka sytuacja nie pozostaje bez wpływu na psychikę, zachowanie, relacje z otoczeniem. Ellen Morgan i Cynthia Klein (2000) w swojej książce opisują studia przypadków dzieci z dysleksją, które świadczą o poczuciu odmienności, odrzucenia, samotności i izolacji. Wyobcowanie, ograniczone uczestnictwo w sytuacjach komunikacyjnych, dodatkowe obowiązki, związane np. z terapią, oraz konieczność wzmożonego wysiłku mogą prowadzić do zakłócenia emocji i nieprawidłowych zachowań społecznych (por. Krasowicz-Kupis 2008).

Michael Thomson (1990) dokonuje podziału reakcji dzieci na trudną sytuację związaną z dysleksją na reakcje wycofywania i kompensacji. W pierwszym przypadku u dziecka występują objawy lęku, często silnego. W drugim - dziecko realizuje się w innych sferach, nie zawsze w sposób aprobowany społecznie, np. dezorganizuje pracę w klasie, błaznuje, jest agresywne.

W literaturze przedmiotu podkreśla się, że najrzadziej stosowaną przez uczniów dyslektycznych strategią jest strategia skoncentrowana na zadaniu (Krasowicz-Kupis 2008; Alexander-Passe 2006). Potwierdzają to w pewien sposób zaprezentowane w niniejszym artykule wyniki badań własnych. Dzieci ryzyka dysleksji w sytuacjach trudnych społecznie zdecydowanie rzadziej niż ich rówieśnicy stosują 
strategię współpracy, która nie tylko skłania do poszukiwania konstruktywnych rozwiązań trudnej sytuacji, ale przede wszystkim pozwala zaspokajać potrzeby jednostki i realizować jej cele we wszystkich zakresach - zarówno indywidualnym, jak i w kontekście utrzymania więzi społecznych.

Angela Fawcett (1995) twierdzi, że dzieci i młodzież ze specyficznymi trudnościami w uczeniu się reagują na stres w różny sposób, w zależności od ich osobowości i temperamentu. O ich psychofizycznym funkcjonowaniu decydują cechy układu nerwowego oraz czynniki ochronne (wparcie ze strony bliskich, sukcesy w innych dziedzinach). Gdy czynniki te nie chronią skutecznie pojawiają się nieefektywne sposoby radzenia sobie ze stresem, takie jak stwierdzona w badaniach własnych strategia unikania czy też opisywana w literaturze przedmiotu - strategia koncentracji na emocjach. Neil Alexander-Passe (2006) podaje, że unikanie jest najczęściej stosowaną przez dzieci ze specyficznymi trudnościami w uczeniu strategią. Nie poprawia ona sytuacji ucznia, wręcz przeciwnie, bywa mylnie interpretowana przez nauczycieli i rodziców jako lenistwo, zła wola czy lekceważenie.

W teorii Erika Eriksona (2000) czas nabywania przez dziecko umiejętności czytania i pisania wiąże się z kryzysem „pracowitość a poczucie niższości”. Doświadczenia dziecka $z$ tego okresu w szczególny sposób wpływają na poczucie tożsamości, które wiąże się z nabywaniem kompetencji. W zależności od wiary we własne możliwości i nadziei na zdobycie osiągnięć dzieci ryzyka dysleksji różnie odczuwają siebie, swoją niezależność, poczucie sprawstwa oraz radzą sobie z problemami i wyzwaniami. Zdecydowanie potrzebują wsparcia prowadzącego do tworzenia poczucia bezpieczeństwa, zmniejszenia stresu, pomocy w opanowaniu kryzysu, pomagania w rozwiązywaniu problemów i przezwyciężaniu trudności.

We wsparcie wpisana jest $\mathrm{z}$ samej swojej istoty akceptacja jednostki przez otoczenie. Środowiskiem najbliższym dziecku jest rodzina i szkoła. Akceptacja rodziców i nauczycieli w stosunku do dziecka powinna przejawiać się przyjmowaniem go takim, jakie ono jest, musi odnosić się zatem zarówno do możliwości, jak i trudności dziecka. Nie oznacza to jednak bezkrytycznego stosunku do dziecka, raczej wiąże się z bezwarunkową akceptacją jednostki, przy warunkowej akceptacji jej zachowań. Wsparcie rodziców i nauczycieli powinno łączyć się z wysokim stopniem empatii, tolerancji, zrozumienia dla potrzeb dziecka, wpisane jest w nie honorowanie indywidualnej linii rozwoju jednostki, niesienie jej pomocy w pokonywaniu trudności. Jest to szczególnie istotne w przypadku dzieci ryzyka dysleksji. Akceptowanie dziecka - jego uczuć, potrzeb, preferencji - buduje w nim zaufanie do siebie i swoich możliwości, rozwija aprobatę dla własnych emocji, kształtuje samoocenę, stanowiąc podstawę jej wzmacniania.

Rodzina i szkoła powinny okazywać dzieciom wsparcie: 
- emocjonalne, którego istotą jest włączenie w sytuacji trudnej emocji uspokajających, pocieszających, łączących się z troską, opieką, poprawiających samopoczucie dziecka;

- informacyjne, polegające na wymianie informacji służących poznaniu problemu, z jakim boryka się dziecko;

- instrumentalne, odnoszące się do wskazania konkretnego sposobu rozwiązania problemu, właściwej strategii radzenia sobie w danej sytuacji trudnej;

- oparte na organizowaniu dystansowania się od problemu i emocji, co ma prowadzić do odwracania uwagi dziecka od trudności (Cywińska 2017).

W szkołach należy tworzyć punkty konsultacyjne, w których dzieci ryzyka dysleksji i dyslektyczne mogłyby liczyć na pomoc wychowawczą i psychologiczną. Oprócz oddziaływań terapeutycznych trzeba pamiętać o podejmowaniu działań profilaktycznych, poszerzających wiedzę na temat danego zjawiska, wpływających na poznanie siebie, świadome ustosunkowanie się i wartościowanie swoich cech fizycznych i psychicznych oraz możliwości.

Sytuacje trudne, przepełnione negatywnymi emocjami wymagają określonej wiedzy i umiejętności umożliwiających dziecku poradzenie sobie z nimi. Ważną rolę w tym zakresie, ze względu na edukacyjne powołanie, ma do spełnienia szkoła, która na stałe - a nie tylko okazjonalnie - do programu nauczania powinna włączyć zajęcia rozwijające kompetencje emocjonalno-społeczne, tak potrzebne $\mathrm{w}$ procesie radzenia sobie w sytuacjach trudnych. Podstawą tych zajęć powinno być uczenie dzieci: rozpoznawania, nazywania i wyrażania emocji, przedstawiania atrybutów uczuć, wzbogacania słownictwa związanego z emocjami, wskazywania źródeł uczuć, rozwijania empatii, radzenia sobie z emocjami negatywnymi, rozumienia komunikatów niewerbalnych, właściwych strategii zachowań w sytuacjach trudnych społecznie, rozwijania umiejętności konstruktywnego rozwiązywania konfliktów, prawidłowego komunikowania się i współpracy z partnerem, inteligencji kreatywnej oraz twórczego rozwiązywania problemów (Cywińska 2017, s. 280). Wyżej wymienione zajęcia powinny być dostosowane do możliwości poznawczych dzieci oraz kontynuowane na kolejnych etapach rozwoju.

\section{LITERATURA}

Alexander-Passe N., 2006, How dyslexic teenagers cope: An investigation of self-esteem, coping and depression. „Dyslexia”, 12(4), 256-275.

Borecka-Biernat D., 2006, Strategie radzenia sobie młodzieży $w$ trudnych sytuacjach społecznych. Psychospołeczne uwarunkowania. Prace Psychologiczne LVIII. Wrocław, Wydawnictwo Uniwersytetu Wrocławskiego. 
Caplan M., Bennetto L., Weissberg R.P., 1991, The role of interpersonal context in the assessment of social problem-solving skills. „Journal of Applied Developmental Psychology", 12, 103-114.

Cichecka-Jusińska I., Pławska K., 2011, Kwestionariusz „Mały Kosmita”. Narzędzie do badania Postaw Radzenia Sobie w Sytuacjach Trudnych Społecznie RSwSTS. Podręcznik testu - wersja dla uczniów szkoły podstawowej klas I-III. Kraków, MEN.

Compas B., Connor-Smith J., Saltzman H., Harding Thomsen A., Wadsworth M., 2001, Coping with stress during childhood and adolescence: Problems, progress, and potential in theory and research. „Psychological Bulletin”, 127 (1), 87-127.

Connor-Smith J., Compas B., Wadsworth M., Harding Thomsen A., Saltzman H., 2000, Responses to stress in adolescence: Measurement of coping and involuntary stress response. „Journal of Consulting and Clinical Psychology”, 68, 976-992.

Cywińska M., 2017, Stres dzieci w młodszym wieku szkolnym. Objawy, przyczyny, możliwości przeciwdziałania. Poznań, Wydawnictwo Naukowe UAM.

Erikson E.H., 2000, Dzieciństwo i społeczeństwo. Poznań, Dom Wydawniczy Rebis.

Fawcett A.J., 1995, Case studies and some recent research. W: T.R. Miles, V. Varma (red.), Dyslexia and Stress. London, Wiley, 13-26.

Krasowicz-Kupis G., 2008, Psychologia dysleksji. Warszawa, PWN.

Lazarus R., Folkman S., 1984, Stress, appraisal and coping. New York, Springer Pub. Co. Łosiak W., 1994, Dynamika emocji i radzenia sobie w stresie psychologicznym. Badania pacjentów chirurgicznych. Kraków, UJ.

Łosiak W., 2008, Psychologia stresu. Warszawa, Wydawnictwa Akademickie i Profesjonalne.

Łosiak W., 2009, Stres i emocje w naszym życiu. Seria „Plus 50”, Warszawa, WAiP.

Morgan E., Klein C., 2000, The Dyslexic Adult in a Non-Dyslexic World. London, Whurr Publishers.

Pincus D.B., Friedman A.G., 2004, Improving children's coping with everyday stress: transporting treatment interventions to the school setting. „Clinical Child and Family Psychology Review, 7(4), 223-240.

Skinder E.A., 1995, Perceived control motivation, and coping. Thousand Oaks, CA: Sage. Terelak J., 1995, Stres psychologiczny. Bydgoszcz, Oficyna Wydawnicza „Branta”.

Thomson M.E., 1990, Developmental Dyslexia. Third Edition. London-Jersey City, Whurr Publishers.

Tomaszewski T., 1982, Człowiek $w$ sytuacji trudnej. W: T. Tomaszewski (red.), Psychologia. Warszawa, PWN, 17-36.

Tomaszewski T., 1984, Ślady i wzorce. Warszawa, WSiP.

Tyszkowa M., 1986, Zachowanie się dzieci w sytuacjach trudnych. Warszawa, PWN. Tyszkowa M., 1997, Odporność psychiczna. W: W. Pomykało (red.), Encyklopedia pedagogiczna. Warszawa, Fundacja Innowacja, 475-478. 


\title{
RISK OF DYSLEXIA AND STRATEGIES OF COPING \\ IN SOCIALLY DIFFICULT SITUATIONS BY YOUNGER SCHOOL-AGED CHILDREN
}

\begin{abstract}
Own conducted studies complement the empirical approach to children's coping with difficult situations. Their aim was to answer the question whether and how the risk of dyslexia affects coping in socially difficult situations by younger school-aged children. The study covered 64 pupils from grades 2 and 3 of elementary schools in the lubelskie province. The core group was made up of pupils with diagnosed risk of dyslexia, and the comparative group was made up of their peers not having specific problems with learning. The studies revealed that there are statistically significant differences in the area of two scales: cooperation and avoidance. Children with a risk of dyslexia in socially difficult situations use the cooperation strategy definitely less seldom than their peers. Instead of an effective strategy of coping in stressful situations, they exhibit various defence methods not focused on resolving and overcoming the problem. An avoidance strategy predominates in this case. In comparison to their peers they definitely more frequently not take steps aimed at resolving a difficult situation. Children with a risk of dyslexia as well as children without learning difficulties use ineffective strategies of coping in difficult situations such as aggression and yielding with similar frequency.
\end{abstract}

Keywords: younger school-aged children, risk of dyslexia, coping in socially difficult situations 